UDC 81'42+808.51]:328.131(41)

DOI https://doi.org/10.32447/2663-340X-2020-8.33

\title{
THE DISCREDITING OPPONENT TACTICS IN THE UK PRIME MINISTER QUESTION TIME DISCOURSE, 09.04.19
}

\author{
Humeniuk Natalia Hryhorivna \\ Candidate of Philological Sciences, Associate Professor, \\ Associate Professor at the Chair of English Philology and Translation \\ Borys Grinchenko Kyiv University \\ Str. Bulvarno-Kudriavska, 18/2, Kyiv, Ukraine
}

\begin{abstract}
The following work deals with the discrediting tactics within the Question Time of the UK Prime Minister, discourse, 09.04.19 investigation. The Question Time of the UK Prime Minister discourse is defined in the given work as subtype of a parliamentary debates discourse with the global strategic purpose to gain and retain power in the country, which is realized through the immediate strategic purposes and by the certain tactics and techniques usage. The discrediting opponent tactics within the Question Time of the UK Prime Minister discourse is determined by the opposition "the UK Prime Minister Boris Johnsons and Opposition MPs with Jeremy Corbyn at the head" and is defined in our work as a communicator actions set to diminish the valuable essence of the leader / member of the opposite, competitive party or of the party as a whole. It is proposed to differentiate the individual and collective opponent. The discrediting tactics within the given discourse are proposed to be grouped and classified into: discrediting tactics dealing with the opponent negative features based on the opponent system of values; discrediting tactics referring also to the self-presenting tactics; insulting technique. The tactics number used by the UK Prime Minister and Opposition MPs to discredit each other differs. It is stated that the UK Prime Minister Boris Johnsons uses a tactics set to discredit the opposite Labour Party with Jeremy Corbyn at the head: "Opponent is a coward" tactics, "Opponent is a criminal" tactics; the discrediting insulting tactics, comparison technique, benefits tactics. It is stressed that the Opposition MPs with Jeremy Corbyn at the head uses a set of discrediting tactics to discredit the UK Prime Minister Boris Johnsons and his Conservative Party: "Opponent is a liar" tactics; "Opponent is non-professional, "incompetent one" tactics; comparison technique.

Key words: Question Time of the UK Prime Minister discourse, discrediting opponent tactics, discrediting insulting tactics, comparison technique, benefits tactics.
\end{abstract}

Problem statement. The given article is devoted to the discrediting tactics problems within the Question Time of the UK Prime Minister (PMQs) discourse, 09.04.19. Being the subtype of the parliamentary debates discourse, which is rather investigated $[1 ; 4 ; 5 ; 6 ; 7 ; 8 ; 9 ; 10 ; 11 ; 12 ; 13$; $14 ; 15 ; 16 ; 17 ; 18 ; 19 ; 20]$, the Question Time of the UK Prime Minister discourse has its specific features which need further investigation. This fact determines the necessity of the given scientific research making it acute.

The aim of the paper is to investigate the discrediting tactics within the Question Time of the UK Prime Minister (PMQs) discourse, 09.04.19, their specific features and realization ways. Simple calculation method, discourse analysis method, immediate constituents method, pure sampling and comparative method are used to realize the aim of the given work.

The material of the article. In reality, the Question Time of the UK Prime Minister (PMQs) is an official process of the UK political life, when the UK Prime Minister (PM) answers questions of the MPs (members of UK Parliament) in the UK Parliament House of Commons during the half an hour period each Wednesday from $12-12.30 \mathrm{p}$. $\mathrm{m}$. This process is broadcasted by radio, TV, the Internet. The material of the Question Time of the UK Prime Minister receives its full transcription in the UK Parliament edition Hansard.

So, the UK Prime Minister as the executive power highest representative organ in the UK - the Government-answers the representatives questions of the highest organ of the legislative power in the country - the MPs of the UK Parliament. This power distribution into the executive and legislative branches in the UK is detached from reality $[11,20 ; 13,123 ; 14]$, because power in the UK is distributed by two main Parties: the Conservative and Labour Party.

At the current period of time, the UK Government is headed by Boris Johnsons, the Conservative Party representative. At the time of the discourse realization Opposition is headed by Jeremy Corbyn, the Labour Party representative. Obviously, the House of Commons becomes an Parties' struggling arena, fighting for power in the country $[11,20 ; 15,209]$.

We consider that the Question Time of the UK Prime Minister as a certain communicative action 
within the UK Parliament has the features of the political, institutional and parliamentary debates discourse.

As the political discourse the Question Time of the UK Prime Minister has its communicative purpose - to fight for power [12, 22- 28; 11, 44].

As the institutional discourse the Question Time of the UK Prime Minister has role-statute distribution of the communicators, the communication purpose, the prototypical place of communication $[6,37-64]$ and, in our opinion, fixed time of its realization, the representation form.

As the parliamentary debates discourse the Question Time of the UK Prime Minister has the communicative purpose to discuss and find solutions for home and oversea problems for the UK within the UK Parliament.

In our work we differentiate the Question Time of the UK Prime Minister as a parliamentary debates discourse subtype with its own specific features. It makes it possible to detach and define the Question Time of the UK Prime Minister discourse as a separate discourse type.

The communicators of the Question Time of the UK Prime Minister discourse are evident: MPs, the UK Prime Minister and Speaker. Their roles during the Question Time are shared: the MPs are to put questions to the UK Prime Minister and Prime Minister is to answer them. Speaker has to regulate and guarantee the order during this process of parliamentary debates.

In this case, the Question Time of the UK Prime Minister discourse is a communicative action in the House of Commons of the UK Parliament, organized in the parliamentary debates form on Wednesday from $12-12.30 \mathrm{p}$. m. by putting questions of the MPs to the UK Prime Minister on the urgent home and outside problems for the UK community and receiving answers for them, as the way to control the UK Government at home and abroad activity.

In its form the Question Time of the UK Prime Minister is a polylogue with strict limits for the UK Prime Minister only to answer questions without putting questions to the Members of Parliament.

In this case, the Speaker, the MPs and the UK Prime Minister put on the addressor information role while organizing and reproducing their messages during the process of the Question Time of the UK Prime Minister and the role of the addressee of information while listening to the messages of the other communicators. At the same time, the potential addressee of this communication - the UK voters, who are absent in the real process of parliamentary debates - fulfills the addressee main role, whom this messages are addressed.
In our work we differentiate the term strategy (or strategic purpose) and tactics (or technique ) of the strategic purpose realization. Strategic purpose of any communication means the aim of it and tactics means the ways of the strategic purpose realization.

Within the term strategy we differentiate the global strategy and immediate strategies, which determine the global strategy within the given communicative situation.

In this case, we define any political discourse global strategic purpose as gaining and retaining the power. The number of the immediate strategies and techniques to realize them may vary: argumentative, appealing, self-praising, storytelling technique, allies-praising, discrediting [7;10, 11]. It depends on several factors: 1) communication vector (cooperative or aggressive); 2) addressee factor; 3) addressor factor (creator of message); 4) communicative situation (time, place, forms and norms of realization); 5) global strategic purpose.

We'd like to add that all these factors are very important to determine the immediate strategies within the given situation and to choose the appropriate ways and means of their realization in the certain tactics form. As any communicative situation is unique because of the mentioned above factors and is not repeated once again because of the time factor it makes any discourse unique with its immediate strategies and tactics of their realization complex.

Our previous investigation shows that the Question Time of the UK Prime Minister discourse is an argumentative discourse. The communicative purpose of the argumentative discourse is "to convince the interlocutor in the addressor's view point and actions correctness, to convince the interlocutor in the necessity to act in the way proposed by the information addressor" [2].

It is evident that it is practically impossible to convince the interlocutor (the opponent parties members) to take the addressor's information view point if they are opponents. In this case, parties try to influence not the opponents but the potential voters.

We can state that MPs prepare their questions to the UK Prime Minister beforehand in logical sequence from argument to argument, from fact to fact. Moreover, the argumentative component of MPs questions consists of 2 main elements: the question itself and the prelude argumentative part of it as arguments series. The position of the Prime Minister is different, he answers the MPs questions with its argumentative part spontaneously.

The analysis of the Question Time of the UK Prime Minister discourse shows that it is rather discrediting than argumentative discourse. 
It is known that any communication type may be either of the cooperative or of the aggressive, confronting, conflict nature, based on the desire of the communicators either to have the cooperative or confronting relations. The cooperative communication presupposes following the cooperative principles described by Leech, Lakkoff, Grice, $[16 ; 19 ; 20]$ and the confronting communication neglects following these principles.

We consider that nature of communication is grounded on the dual nature of its creators human beings, who in their nature have the animal, or beast, and social features. This inner struggle between the animal and social essence within the person is dialectal. The greater share of one of them determines the communicative vector - aggressive or cooperative one. Moreover, communication creators intentionally choose this or that communication vector, either to be leaders, to dominate, to fight and win, to get a victory or to cooperate, to collaborate, to find compromises.

It is proved that any political discourse, and the Question Time of the UK Prime Minister as part of it, is an aggressive, conflict communication with the purposes 1) to discredite opponents; 2) to praise the allies; 3) to make self-praising, self-presentation $[10,11]$. To our mind, in reality the process of discrediting opponents and of selfpraising, self-presenting are intercollective ones, which presupposes the presence of both of them.

It's known that discrediting means to diminish somebody's authority, significance and importance $[10,21]$. Any communication based on the opponent communicators discrediting is a conflict, aggressive and confronting communication, the aim of which is to dominate, to be the leader, deprive opponents to be leaders.

We can state that the Question Time of the UK Prime Minister in the House of Commons resembles the fight, the battle between the UK Prime Minister and the MPs from the opposite Party, each of them tries to win the victory of it - to discredit each other, by appealing to the persons' emotions and feelings, values and wishes - the inhabitants of the UK.

In our work we differentiate 2 types of opponents: 1) the collective opponent (the competitive parties themselves); 2) the individual opponent (the leaders of the parties, the members of the parties).

So, the discrediting technique within the Question Time of the UK Prime Minister discourse is aimed either to discredit, to diminish the collective opponent's importance and value competitive party - or of the individual opponent competitive parties' leaders and members.

Based on the fact that the Conservative and Labour Parties are in constant process of power struggling and the UK Prime Minister as the Conservative Party' representative is opposed to the Labour Party MPs, the number of questions given by the Conservative Party representatives to the UK Prime Minister is lower than the questions number given by the opponents - the representatives of the Labour Party.

The the Question Time analysis of the UK Prime Minister shows that the number of questions given to the UK Prime Minister Boris Johnsons by the leader of the Labour Party Jeremy Corbyn, the head of Opposition in the House of Commons, is the highest. So, this discourse is a battle between two leaders of the competitive parties. Their attempts to diminish the valuable essence either of the collective or individual opponents of the competitive party is nothing but verbal attack [7, $31-32]$ to the competitive party leader or the party as a whole.

We can state that the portion of the verbal attacks to discredit the individual opponent - the leader of the competitive party - prevails within the Question Time of the UK Prime Minister in comparison with the verbal attacks to discredit the collective opponent.

In our work we define the process of discrediting somebody, something with the locating process, gradation some ideas of the things, phenomena, processes from reality on the appraisal scale. The process of gradation the ideas of real things, phenomena, processes on the appraisal scale means to locate these ideas in accordance to neutral, negative or positive grades within the goodness/ evilness, usefulness/ harmfulness for the human beings [3]. In this case, to discredite somebody, something means to locate the idea of the discredited item on the negative grade of the appraisal scale or, in other words, to give it negative evaluation.

So, it is obvious that a great language unit number with negative meaning are used to discredit opponents within the UK Prime Minister Question Time discourse: surrender, poverty, coward, sham, shameless.

Generally speaking, gradation is done into useful and harmful, good and evil and is normative for human beings as any person has a chance to make a choice, to choose an item, a process, a behavior type to follow, an action type and deed to fulfill from positive and negative sets. In other words, gradation is done into good and evil, useful and harmful and its choice is determined by system of values, relevant and important ideas for the individual.

Traditionally, all values are subdivided into positive, or moral values, and negative, or immoral values. This traditional classification with its moral 
and immoral values was proved by long-term human practice and reflects the general human society social direction - the necessity to distant and avoid harmful and useless items and that for the peaceful co-existence of all human society members with their respect to each other. But any person having his/her individual experience and matters universe understanding may neglect this traditional long-term practice with its division into good and evil, making his/her priority system.

The UK Prime Minister discourse Question Time analysis shows that the opponent tactics discrediting are based on the opponents negative evaluation, individual or collective, by correlating, identifying the opponent with negative, immoral values system in all spheres of his/her/their life.

Generally speaking, the number of negative, immoral values and the number of human life spheres presuppose a great discrediting tactics, techniques quantity.

The analysis of the Question Time of the UK Prime Minister discourse shows that opponents were discredited in accordance to: 1) personal, individual life (character features, relations with relatives, friends): 2) professional life ( ability to fulfill the appointed position tasks) 3) relations with law and legal system; 4) political life.

Grounding on the factor of negative, immoral values and the human life spheres we have determined and grouped all the discrediting tactics within the Question Time UK Prime Minister discourse into:1) Opponent is a liar; 2) Opponent is a coward; 3) Opponent is non-professional, incompetent; 4) Opponent is a criminal.

According to the investigation results we can state that discrediting tactics of the MPs of Opposition with Jeremy Corbyn at the head to discredit the UK Prime Minister Boris Johnson are the following:

a) Opponent is a liar:

\section{Jeremy Corbyn}

\section{Share}

He is obviously so confident of the position that he has adopted that he is now prepared to spend $£ 100$ million of our money on an advertising campaign to try to persuade people that everything is fine. He knows it is not, and they know it is not. He is hiding the facts [21].

The oppositions "he - they", "everything is fineit is not", word combination with explicit negative meaning "hiding the facts" and word combination with the contextual negative meaning "to spend $£ 100$ million of our money on an advertising campaign" are used by Jeremy Corbyn to prove that the UK prime Minister Boris Johnsons is a liar, who hides facts and manipulates information for his own interests and interests of his party. b) Opponent is non-professional, incompetent:

1. Jeremy Corbyn

Share

My first question to the Prime Minister, and no answer given! I asked what proposals had been put to the EU. We asked yesterday-many colleagues asked-and he seems utterly incapable of answering. [21].

The given example contains the oppositions "question-answer", "I(my)/we - he", which stress the opposite relations between the communicators, and contain the phrase "... he seems utterly incapable of answering", which is intended to prove Boris Johnsons' incompetence.

The Question Time analysis of the UK Prime Minister discourse shows that the UK Prime Minister Boris Johnsons uses such discrediting tactics to diminish the valuable essence of the opponent, competitive party and its leader Jeremy Corbyn as:

a) Opponent is a criminal, illegal, having bad reputation:

\section{The Prime Minister \\ Share}

Gentleman's surrender Bill would wreck a ny chances of the talks. We do not know what his strategy would be if he took over. He is asking for mobs of Momentum activists to paralyse the traffic [21].

\section{The Prime Minister \\ Share}

He makes a contrast between this Government and his own proposals. The contrast could not be clearer: we think that the friends of this country are to be found in Paris, in Berlin and in the White House, and he thinks that they are in the Kremlin. in Tehran and-[Interruption.] He does. And in Caracas - [21].

The first example includes the words and word combination with negative meaning surrender, wreck, paralyze the traffic and word combination mobs of Momentum activists with the meaning "criminals, mafia". Using them the UK Prime Minister Boris Johnsons tries to show the UK voters that Jeremy Corbyn's actions and the Labour Party anti-Brexit protests are illegal, that the Labour Party's leader has connections with criminals and mafia, which may be harmful for the UK community.

The second example is given in the comparison form, so it is also known as comparative tactics. The opposition "We (we, this Government, this country) - he (he, his proposals)" is concerned with the friends, allies of both sides. The UK Prime Minister tries to prove the UK voters that allies of his Conservative Party are highly developed, highly civilized countries with the governments located in Paris, in Berlin and in the White House, 
while allies of the opposite Labour Party with its leader Jeremy Corbyn have bad reputation and their governments are located in criminal Kremlin, in terroristic Tehran, in mafia Caracas. The UK Prime Minister Boris Johnsons tries to prove that Labour Party binds with criminal allies may be harmful for the UK community.

b) Opponent is a coward:

The given tactics is realized through the usage of the word frightened and word combination dither and delay, which is repeated several times within the Boris Johnsons' message, to prove that Jeremy Corbyn is coward to make decisions, to make changes, to realize strategically necessary plans of the country development.

\section{The Prime Minister}

Share

I really do not see how with a straight face the right hon. Gentleman can accuse anybody of being unwilling to stand up to scrutiny when he will not agree to submit his surrender Bill to the verdict of the people in an election. He is frit; he is frightened. [21].

2. What are they supposed to chant? What is the slogan? "What do we want? Dither and delay [the same].

We differentiate the other discrediting tactics which at the same time also belong to the selfpresenting tactics: 1) comparison technique to show the advantages of themselves and disadvantages of the opponents; 2) benefits tactics to show pluses and strong positions of themselves.

Realization of the benefits tactics we can see in the following example, when the UK Prime Minister tries to show pluses of his Conservative Party ruling the country ( $I$, this Conservative Party ) by using the economics term living wage, words with positive meaning proud, thanks to, by using the contextually positive word combination $£ 4,500$ more every year than they were in 2010 :

The Prime Minister

Share

I am proud to say that those on the living wage are now taking home $£ 4.500$ more every year than they were in 2010, thanks to this Conservative Government. [21].

The comparison tactics is used all over the verbal fight between two leader of the opposite parties, when each side tries to show their advantages and opponent disadvantages:

The Prime Minister

\section{Share}

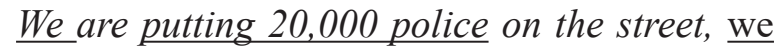
have 20 new hospital upgrades, we are growing the economy. The right hon. Gentleman, by contrast, would put a £300 billion tax on every company in the country, he wants a tax on homes, and he is calling incessantly for a general strike. [21].

The given tactics is realized through the usage of the opposition we - he (gentleman) and the contextually positive and negative word combinations where positive ones are the following: putting 20,000 police. growing the economy, 20 new hospital upgrades and negative ones are $£ 300$ billion tax on every company in the country, a tax on homes, general strike.

The discrediting tactics of insulting, mocking, ridiculing stands apart from the given above classifications. This tactics is an immediate explicit verbal attack of the highest rank. The person who uses this tactics does know the results of it: it may be the insulting, mocking feedback or even physical attack - an immediate physical contact, an immediate physical fight.

The discrediting tactics of insulting is used 5 times by the UK Prime Minister Boris Johnsons:

1. ... and I think he is "caracas"! [21].

2. The shadow Education Secretary says that Labour's economic policy is-and I quote, by your leave, Mr. Speaker_-"shit-or-bust"; I say it is both. (the same).

3. He is frit. ( 2 times) (the same).

4. Gentleman is worried about free trade deals with America, but I can see only one chlorinated chicken in the House, and he is sitting on the Opposition Front Bench (the same).

All the examples of the discrediting tactics realization include the usage of metaphors, which makes it possible to transfer some qualities of one object to another one.

To sum up the material we can state that the discrediting opponent strategy within the Question Time of the UK Prime Minister discourse is realized in the form of several discrediting tactics: a) Opponent is a liar; b) Opponent is coward; c) Opponent is non-professional, incompetent; d) Opponent is criminal; e) the discrediting tactics of insulting $\mathrm{f}$ ) comparison technique; g) tactics of benefits. The number of tactics used from the opposite sides - the UK Prime Minister Boris Johnsons and Opposition MPs with Jeremy Corbyn at the head - varies.

The UK Prime Minister Boris Johnsons uses such discrediting tactics to diminish the valuable essence of the opposite Labour Party and its leader Jeremy Corbyn as: a) Opponent is coward; b) Opponent is criminal; c) the discrediting tactics of insulting d) comparison technique; e) tactics of benefits.

The MPs of the Opposition with Jeremy Corbyn at the head uses the set of discrediting tactics to discredite the UK Prime Minister Boris Johnsons 
and his Conservative Party: a) Opponent is a liar; b) Opponent is non-professional, incompetent; d) comparison technique.

Conclusions. Summing up the material, we can state that the Question Time of the UK Prime Minister discourse as a certain type of the parliamentary debates discourse has the global strategy to gain and retain power, realization of which depends on realization of some immediate strategic purposes and on the usage of some tactics and techniques. The discrediting opponent tactics within the Question Time of the UK Prime Minister discourse are determined by the intention of the UK Prime Minister Boris Johnsons, the representative of the Conservative Party, and the MPs of the Opposition with Jeremy at the head, the representatives of the Labour Party, to discredite each other, to diminish the valuable essence of the leader, member of the opposite, competitive party or party as a whole, known as individual and collective opponents. The discrediting individual opponent tactics prevails within the Question Time of the UK Prime Minister discourse. The given discourse is a battle of two leaders - Boris Johnsons and Jeremy Corbyn - to discredite each other. For the purposes of the discrediting opponent a set of tactics is used: 1) discrediting tactics dealing with the opponent negative features based on the opponent system of values; 2) discrediting tactics referring also to the self-presenting tactics and 3 ) insulting technique. The number of the discrediting tactics differs from each side.

It is perspective to investigate the realization of the discrediting tactics of the opposite sides within the Question Time of the UK Prime Minister discourse, to investigate the usage of stylistic devices and expressive means within the Question Time of the UK Prime Minister discourse to provoke the attention of addressee to the ideas given in the discourse.

\section{BIBLIOGRAPHY}

1. Басюк Л.М. Дебати в парламентському дискурсі Великої Британії і США : лінгво-прагматичний аспект : Автореф. дис. ...канд. філол. наук : 10.02.04. Київський університет імені Бориса Грінченка. Київ, 2019. 20 с.

2. Бєлова А. Лінгвістичні аспекти аргументації (на матеріалі сучасної англійської мови) : автореф. дис. ... докт. філол наук. : 10.02.04. Київський університет імені Тараса Шевченка. К., 1998. 287 с.

3. Вольф Е.М. Функциональная семантика оценки. М.: Наука, 1985. 224 с.

4. Дьяченко Н. М., Халін В. В. Комунікативні стратегії в сучасному українському політичному дискурсі. Вісник Житомирського державного університету імені Івана Франка. Сер.: Філологія. 1 (89). 2019. С.56 - 62.

5. Зернецька О. В., Зернецький П. В. «Чи прийме парламент нашу подяку?» Дещо про мовний вишкіл британських парламентарів. Віче. 2004. № 9. С. 73 - 74.

6. Карасик В. И. Этно-культурные типы институционального дисукрса. Этно-культурная спещифика речевой деятельности. Сб. обзоров. М.: ИНИОН РАН, 2000. С. 37 - 64.

7. Крячкова А. П. Лингопрагматические средства реализации вербальных атак на имидж политических партий Германии : дис. ...канд. филол. наук : 10.02.04. Московский гос. ин-т международных отношений. М., 2019. 170 с.

8. П'єцух О. І. Емотивність політичного дискурсу парламентських дебатів у Сполученному Королівстві. Науковий вісник Міжнародного гуманітарного університету. Сер.: Філологія. № 25. Т. 2. 2016. С. 103 - 105.

9. П'єцух О. І. Нормативність політичного дискурсу парламентських дебатів у Сполученному Королівстві Великої Британії та Північній Ірландії. Science and Education a New Dimention. Philololgy. Т ( 31). № 118. 2017. С. 61 - 64.

10. Руженцева Н.Б. Дискредитирующие тактики и приемы в российском политическом дискурсе : монография. Уральский гос. пед. ун-т. Екатеринбург, 2004. 294 с.

11. Рябоконь Г. Л. Дискурсивні особливості інтернет публікацій дебатів Британського парламенту : дис. ...канд. філол. наук : 10.01.08. Нац. університет "Київо-Могилянська академія". Київ,2009. 276.

12. Шейгал Е. И. Структура и граница политического дискурса. Филология- Philologica. Краснодар, 1998. С. 22 - 29.

13. Coxall B., Robins L. Contemporary British Politics. NY: Palgrave Macmillan, 1994. P. 509.

14. Coxall B., Robins L., Leach R. Contemporary British Politics. NY: Palgrave Macmillan, 2003. P. 452.

15. Forman F.N. , Baldwin N. B. Mastering British Politics. Macmillan, 1996. 478 p.

16. Grice H.P. Logic and Conversation. Syntax and semantics. Vol. 3. Speech acts; P. Cole, J.L. Morgan (eds.). New York: Academic Press, 1975. P. 41-58.

17. Humeniuk N. H. Storytelling technique in the Boris Johnsons' first speech as a Prime Minister, 07. 24. 19. Вчені записки ТНУ імені В. І. Вернадського. Серія: Філологія. Сощіальні комунікащії. Т. 30 (69). Ч. 2. № 4. Видавничий дім «Гельветика», 2019. С. $32-35$.

18. Humeniuk N. H. Pragma-communicative aspects of the Boris Johnson' first speech as a Prime Minister (July, 24, 2019). Закарпатські філологічні студії. В.12. Видавничий дім «Гельветика», 2019. С. 68-74.

19. Lakoff, R. The logic of politeness Or, minding your p's and q's. C. Corum, T. Cedric Smith-Stark, \& A. Weiser (Eds.). Papers from the 9th Regional Meeting of the Chicago Linguistic Society. Chicago Linguistic Society, 1973. P. 292 -305. 
20. Leech G.N. Principles of pragmatics. London: Longman, 1983. 250 p.

21. Parliament UK. Commons. 2019-09-04 Debates. Hansard, 2019. [Електронний ресурс ]- Режим доступу: https:// hansard.parliament.uk/commons/2019-09-04/debates/917B81A6-57F8-48C3-AABE-63224897F16E/Engagements

\title{
REFERENCES
}

1. Basiuk L.M. ( 2019 ). Debaty v parlamentskomu dyskursi Velykoi Brytanii i SSA: linhvo-prahmatychnyi aspekt: avtoreph. dys. ... kand. philol. nauk : 10.02.04. [Debates in the parliamentary discourse of Great Britain and the United States: linguistic-pragmatic aspect: abstract. diss. ... cand. philol. sciences: 10.02.04]. Kyivskyi universitet imeni Borysa Grinchenko. Kyiv, 2019. 20 p. [in Ukrainian].

2. Belova A.( 1998 ). Linhvistychni aspekty arhumentatsii (suchasna anhliiska mova): dys. ....dok. philol. nauk : 10.02.04. [ Linguistic aspects of argumentation (contemporary English): dis.... doc. philol. of sciences. : 10.02.04]. Kyivskyi universitet imeni Tarasa Shevchenka. K., 1998. 287 p. [in Ukrainian].

3. Volf E.M. Funkcionalnaya semantika ocenki. [Functional semantics of appraisal]. M.: Nauka, 1985. 224 p. [in Russian].

4. Diachenko N.M., Khalin V.V. ( 2019 ).Komunikatyvni stratehii v suchasnomu ukraiinskomu politychnomu dyskursi. [Communicative strategies in contemporary Ukrainian political discourse]. Visnyk Zhytomyrskoho derzhavnoho universitetu imeni Ivana Franka. Ser .: Philology. 1 (89). 2019. P.56 - 62 [in Ukrainian].

5. Zernetska O.V, Zernetsky P.V. ( 2004 ). Shchi pryime parlament nashu podiaku? Deshcho pro movnyi vyshkil brytanskykh parlamentariv. ["Will Parliament accept our thanks?" Something about the language training of British parliamentarians]. Viche. 2004. № 9. P. 73 -74 [in Ukrainian].

6. Karasik V. I. ( 2000 ). Etno-kulturnye tipy institucionalnogo diskursa. [Ethno-cultural types of the institutional discourse]. Ethno-cultural specificity of speech activity. Coll. reviews. M.:INION RAN, 2000, P. 37 - 64 [in Russian].

7. Kryachkova A.P. Lingvopragmaticheskie sredstva realizacii verbalnyh atak na imidzh politicheskih partii Germanii : diss. ... kand. philol. nauk : 10.02.04. [Linguo-pragmatic means of the verbal attacks of the political parties image :diss. ... cand. philol. sciences: 10.02.04]. Moscow state institute of the international affairs. M., 2019. 170 p. [in Russian].

8. Pjetsukh O. I. ( 2016 ). Emotyvnist politychnoho dyskursu parlamentskykh debativ u Spoluchennomu Korolivstvi Velykoi Brytanii. [Emotiveness in the political discourse of the UK Parliamentary debates]. Naukovyi visnyk Mizhnarodnoho humanitarnoho universitetu. Ser. : Philolohiia. Vol. 2 № 25. 2016. P. 103 - 105.[in Ukrainian].

9. Pjetsukh O. I. ( 2017). Normatyvnist politychnoho dyskursu parlamentskykh debativ u Spoluchennomu Korolivstvi Velykoi Brytanii. [ Normativity in the political discourse of the UK Parliamentary debates]. Science and Education a New Dimention. Philology. Vol. 31 № 118. 2017. P. 61 - 64 [in Ukrainian].

10. Ruzhenceva N.B. ( 2004 ). Diskreditiruiushpie taktiki i priyomy v rossijskom politicheskom diskurse: monographiya. [ Discrediting tactics and techniques in Russian political discourse: a monograph]. Uralskij gos. ped. universitet. Ekaterinburg, 2004. 294 p. [in Russian].

11. Riabokon H. L. ( 2009 ). Dyskursyvni osoblyvosti internet publikatsii debativ Brytanskoho parlamentu: dys. ... kand. philol. nauk; 10.01.08. [Discourse features of the online publications of the British Parliament debates: diss. ... Cand. philol. Sciences: 10.01.08. ] Natsionalnyi Universitet "Kyivo-Mohylianska Academiia". Kyiv, 2009. 276 p. [in Ukrainian].

12. Sheigal E. I. ( 1998 ). Structura i granica politicheskogo diskursa. [The structure and boundary of political discourse]. Philologiya. Krasnodar, 1998. P. 22 - 29 [in Russian].

\section{ДИСКРЕДИТУЮЧІ ОПОНЕНТА ТАКТИКИ У ДИСКУРСІ ВІДПОВІДІ НА ЗАПИТАННЯ ПРЕМ'СР МІНІСТРА СПОЛУЧЕНОГО КОРОЛІВСТВА У ПАРЛАМЕНТІ, 04.09.19}

\author{
Гуменюк Наталя Григорівна \\ кандидат філологічних наук, дочент, \\ доцент кафедри англійської філологї та перекладу \\ Киівського університету імені Бориса Грінченка \\ вул. Бульварно-Кудрявська, 18/2, Київ, Украӥна
}

Подана робота присвячена розгляду дискредитуючих опонента тактик у дискурсі відповідей Прем'єр міністра Сполученого Королівства на запитання у парламенті від 04.09.19. В межах проведеного дослідження дискурс відповідей Прем'єр міністра Сполученого Королівства на запитання у парламенті визначено як підтип парламентських дебатів із глобальною стратегічною метою отримати та утримати владу в країні, яка реалізується за рахунок вирішення безпосередніх стратегічних завдань та з використанням певних тактик та технік. Тактика дискредитації опонента в межах дискурсу відповідей Прем'єр міністра Сполученого Королівства 
на запитання у парламенті визначається опозицією "Прем'єр міністр Сполученого Королівства Борис Джсосон та опозииійні парламентарі з Джеремі Корбін на чолі", в роботі тактику дискредитаиії подано у вигляді набору дій комуніканта з метою зменшити иіннісну значимість лідера / члена опозиційної партії або ж партії в иілому. Запропоновано диферениіювати індивідуального та колективного опонента. Тактики дискредитації опонента в межах поданого дискурсу запропоновано групувати та класифікувати на : тактики дискредитації, пов'язані з негативними особливостями опонента, які базуються на системі релевантних для опонента иінностей; тактики дискредитаиї, які також мають відношення до тактики само-презентації; тактики образи. Кількість тактик, використаних Прем'єр міністром Сполученого Королівства та опозиційними парламентарями для дискредитації один одного, відрізняється._Зазначено, щяо Прем'єр міністр Сполученого Королівства Борис Джонсон з метою дискредитації опозииійної Лейбористської партії з Джеремі Корбін на чолі використовує дискредитуючі опонента тактики: тактику «Опонент - боягуз», тактику «Опонент - кримінальний елемент», порівняльну техніку, тактику переваг. Підкреслено, щзо опозиційні парламентарі з Джеремі Корбін на чолі з метою дискредитаціï Прем'єр міністр Сполученого Королівства Борис Джонсон та його Консервативної партії використовують дискредитуючі опонента тактики: тактику «Опонент - брехун», тактику «Опонент непрофесіонал, не компетентний», техніку порівняння.

Ключові слова: дискурс відповіді Прем'єр міністра Об'єднаного Королівства на запитання у Парламенті, дискредитуюча опонента тактика. тактика образи, порівняльна техніка, тактика переваг. 